International Research Journal of Engineering, IT \& Scientific Research
Available online at https://sloap.org/journals/index.php/irjeis/
Vol. 6 No. 2, March 2020, pages: $39-46$
ISSN: 2454-2261
https://doi.org/10.21744/irjeis.v6n2.862

\title{
Measuring Optimization of Digital Military Programs: An Innovation of Information and Communication Systems in Industrial Digitalization 4.0
}

I Gd. Wahyu Utomo a Gede Sri Darma ${ }^{\text {b }}$

Article history:

Submitted: 27 November 2019

Revised: 09 December 2019

Accepted: 31 January 2020

Keywords:

communication networks; digital military;

digitalization 4.0;

Indonesian national army;

information systems;

\begin{abstract}
This research examines military digital optimization as an information and communication system innovation in the industrial digitalization era 4.0. Advances in information and communication technology especially on the industrial revolution 4.0. The real impact is seen in several aspects of humanlife. The industrial revolution 4.0 also provided a change in the government system into good governance. Technological advances also have an impact on the defense system or military system in Indonesia, especially for the Indonesian National Army, especially the (TNI AD) through the use of an emilitary application system to facilitate the search for internal information related to TNI personnel. The research method is descriptive qualitative with a sampling technique that is purposive sampling. Kodam IX / Udayana, Denpasar, Bali as a location of this study. Data collection uses a structured interview method to a number of informants who have been willing to engage a number of 13 people. The method of analyzing data uses a data coding system and based on the percentage of satisfaction using e-military applications became a conclusion. Research results show that based on response data related to the use of e-military applications, the implementation of Military Digital Applications in Kodam IX / Udayana is quite good at $60.65 \%$. The theoretical implication of this research is that it has been able to prove the role of Delone and McLean's information system success theory models in explaining how the implementation of Optimization of Military Digital Applications as Information and Communication Systems Innovation in the Era of Industrial Digitalization 4.0 at Kodam IX / Udayana Denpasar, Bali.
\end{abstract}

International research journal of engineering, IT \& scientific research (C) 2020. This is an open access article under the CC BY-NC-ND license (https://creativecommons.org/licenses/by-nc-nd/4.0/).

Corresponding author:

I Gd. Wahyu Utomo,

Undiknas Graduate School, Denpasar, Indonesia

J1. Waturenggong No.164 Denpasar, Bali, Indonesia

Email address: kambingcowok@gmail.com

a Undiknas Graduate School, Denpasar, Indonesia

b Undiknas Graduate School, Denpasar, Indonesia 


\section{Introduction}

The industrial revolution 4.0 has brought changes in all lines of human life. One of the progress felt is in the field of information technology which is experiencing very rapid development. All needs related to access to information can be easily accessed and accessed. The industrial revolution 4.0 also shifted the traditional governance paradigm towards good governance. Good governance is a governance system that is participatory, effective, honest, fair, transparent, and has overall responsibility for both vertical and horizontal accountability (Azhari et al., 2013).

Efficiency and effectiveness become part of the principle of good governance, through the management of resources efficiently (efficiently) and effectively (effectively). To achieve good governance an E-Government concept is needed, through the use of technological advancements to drive the axis of government. Technology development also impacts one of them is in the world of military defense, so a change in the military industry is known as revolutionary in military affairs (RMA). Deloitte defines Industrial Revolution4.0. It can improve military readiness through the optimization and relevance of the use of military technology in both weapons systems, human resource quality, and shifts in values and culture and social interaction (Dewi et al., 2018; Yoga et al., 2019).

Military forces in Indonesia known as the Indonesian National Army (TNI) also have the same guidance in the era of the digital and industrial revolution 4.0. The year 2008 in accordance with Kasad regulation (Perkasad) Perkasad Number / 112 / XII / 2008 concerning the instructions for the use and payment of telecommunications services in the ranks of the Indonesian National Army, especially those serving in the Army (Army AD). Based on the Decree, a data communication network was built that could connect units within the ranks of the Army, called the Electronic Military Mail (E-Military) of the Army. E-Military itself will replace the previous Radio Over Internet Protocol (RoIP) communication tool. The use of E-military is very limited. According to the unique manual for the operation of the TNI AD e-military in 2009, it was stated that the E-Military ranks of the TNI AD were a means of communication organized to support the field of transportation both data communication and voice communication.

In this study the Kodam IX / Udayana was chosen as the location of the study because the area to be managed included three provinces namely Bali, East Nusa Tenggara and West Nusa Tenggara. According to the policy of the TNI commander. Kodam is the frontline defense on land. Good coordination will be created if the media chosen is right. In addition, the real demand in the digital reform era 4.0 is that information must be accurate, fast and reliable. Using commercial aids is easier, but the challenge is to be vulnerable to leaking through various tapped channels. TNI Unity requires in-depth development of information systems such as e-military in order to optimize troop performance. Based on this description, researchers are interested in researching the optimization of military digital applications as information and communication system innovations in the era of digitizing industry 4.0, especially in Kodam IX / Udayana.

\section{Literature review}

\section{DeLone and McLean's Information System (IS or Information System) Success Model}

The first model of the DeLone and McLeanISsuccessmodeling theory states that the elements of the success of the information system include Information Quality, System Quality, Usage, User Satisfaction, User Impact, Organizational Impact. These parameters affect each other (not separate). Through a number of retesting tests, the IS successDeLone and McLean1992 driving model is developed by maintaining the usage variable but the intensity of use is added, taking into consideration that the system's usability can better measure the success of the system compared to its use alone. The next generation developed the success model, 2003 model.

Delone \& McLean (2003), state that the interaction between the user and the system that has been modified is strong, but on the other hand the interaction between system usability and user satisfaction is considered low even though the interaction of other variables is good enough, therefore, IS success model is adopted until now. This was later modified by Almazan et al. (2017), Net Benefits was changed to an organizational resource, referring to the DeLone and McLean models of 1992. This model was adopted modified in this study (Xavier, 2015; Castillo et al., 2016).

\section{Information Systems}

According to Raymond Information systems are defined as technology-based systems that provide information for users according to their needs (Teguh, 2005). According to Huang and Nof (2002), states that information systems 
can improve company activities in various fields such as collaboration, decision-making processes, and logistics. There are two (2) factors inhibiting the implementation of information systems are as follows presented by (Juniar, 2013) namely human resource factors include lack of technological skills, poor management, infrastructure and technical factors including inadequate infrastructure, technical errors in information system applications, inappropriate implementation of information systems, lack of security systems.

\section{Application}

Complete Dictionary of the World of Computers (2002) defines application as data processing activities with specific objectives in an organization. The purpose of making an application is to help solve a problem such as a specific problem such as information system applications. In the digital revolution era 4.0, many new applications have emerged to support and facilitate human activities. If described, the computer is the hardware as a home, while the application is software that can develop along with the development of technology or existing hardware.

\section{Personnel information system application}

Based on Kasadad Regulation Perkasad / 20 / VIII / 2012 about the use of information systems within the Indonesian Armed Forces (TNI AD) states that the existing information system within the Army AD in general and Kodam IX / Udayana, in particular, uses the E-Military network. The personnel application system began to be used in full based on the Kasad telegram letter No. ST / 3661/2017 concerning the order to carry out the dissemination of the 2017 version of the online sisfopers application of the Indonesian Army.

The online sisfopers application is the basis for the data processing of personnel of the Indonesian Army inactive status both within the Indonesian Army Structure and outside the Army. The data includes the main data of soldiers, starting from the first appointment to the last position as well as additional data needed by the Army both personal and family data. So, it can be said as a complete integrated one-door internal network and can be accessed according to the needs of internal information quickly and easily. The results of the processing of the Personnel Information System by Infolahta are then reported to the Assistant Personnel to manage personnel at Kodam IX / Udayana so that the need for valid data is very important for elements of the leadership of the Army in determining policies/decisions in the context of developing manpower and fostering personnel of the Army.

\section{E-Military network}

Understanding of the E-Military network According to the technical manual for the operation of the E-Military Data Communication of the Indonesian Army issued by the Directorate of Army Transportation and Army Chief of Staff Regulation No. Perkasad / 112 / XII / 2008 dated December 24, 2008, concerning instructions for implementing the use and payment of facility services general telecommunications in the ranks of the Army, which states that EMilitary Data Communication (Military Electronic Mail) The ranks of the Army AD is a means of communication organized to support the field of communication both data communication and voice communication.

E-military uses a VPN (virtual private network) technology that is spread throughout the ranks of the Indonesian Army. Management of this application in collaboration with PT. Telkom as an internet network provider. With the existence of this E-Military network in addition to the speed of searching for accurate information, also in terms of data security in accessing information systems to be more secure, the most important aspect of security is data confidentiality (Confidentially), because military agencies are closely related to confidentiality.

\section{Framework}

The framework of thought in this study is illustrated in Figure 1. The problem was examined using the Delone and McLean Information System Success Model (2003) to analyze the optimization of the Digital Military program at Kodam IX / Udayana. The six elements that are used as indicators are System Quality, Information Quality, Use, User Satisfaction, Individual Impact, and Organizational Impact. The focus of research is directed at the application of Personnel Information Systems (SISFOPER) which is part of the E-Military application. This program is a form of TNI AD innovation in improving the quality of performance of military organizations so that they can work quickly, precisely and safely supporting performance in the era of industrial digitalization.

Utomo, I. G. W., \& Darma, G. S. (2020). Measuring optimization of digital military programs: an innovation of information and communication systems in industrial digitalization 4.0. International Research Journal of Engineering, IT \& Scientific Research, 6(2), 39-46. https://doi.org/10.21744/irjeis.v6n2.862 


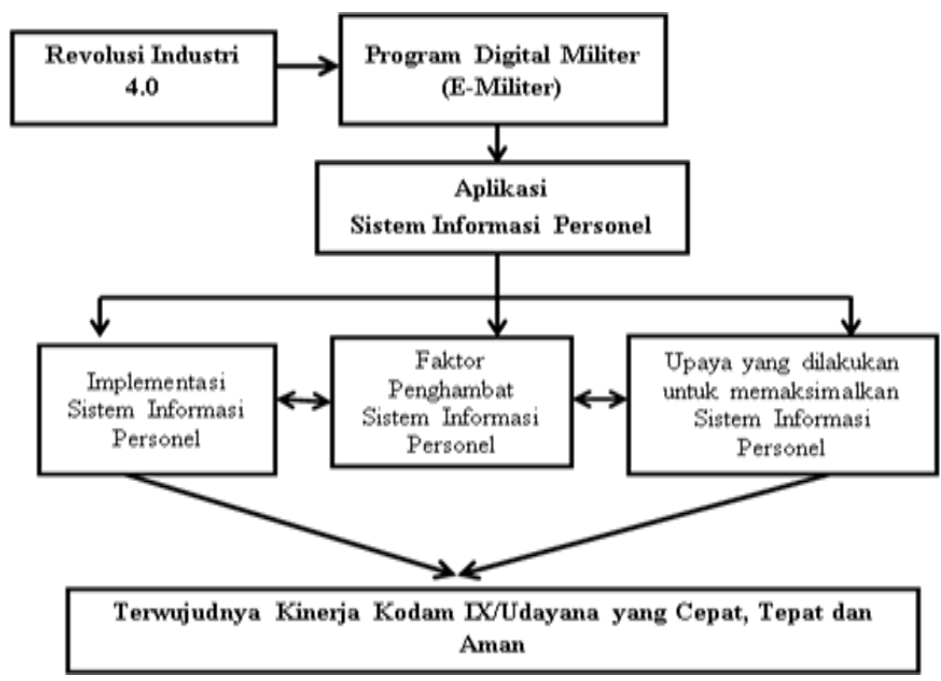

Figure 1. Research thinking framework

\section{Materials and Methods}

This research was conducted in three work units namely Hubdam IX / Udayana for the reason because Hubdam IX / Udayana as the manager of e-military networks in Kodam IX / Udayana, Infolahtadam IX / Udayana, on the grounds that Infolahta was the Supervision of Personnel Information System application, which carried out examination of data entered by the satker operator, Assistant Personnel (Aspers) Kodam IX / Udayana on the grounds because Aspers Kodam IX / Udayana as personnel management at Kodam IX / Udayana.

Qualitative data in this study were obtained through a description of the location of the study, a general description of the subject and object of research, data from observations and interview data. The quantitative data in this study were obtained through organizational structure data, staffing, implementation data and the use of the Digital Military (E-Military) program precisely the use of Personnel Information System Applications at Kodam IX Udayana and other supporting data (DeLone \& McLean, 1992; McLeod \& Schell, 2004).

Interviews with informants using interview guides contain question items that refer to how to optimize the Digital Military (E-Military) program specifically the utilization of Personnel Information System Applications at Kodam IX Udayana. Determination of the sample through a purposive sampling technique by determining specific criteria for finding informants to be interviewed.

\section{Results and Discussions}

Based on the results of interviews, analysis, and observations made by researchers, data obtained related to the implementation of e-military applications, as well as factors that hinder actualization and optimization of performance, as well as efforts made to maximize actualization and optimization of Digital Military application performance at Kodam IX / Udayana.

Figure 2 shows the respondent's response to the implementation of the digital military program as an information and communication system innovation: 


\begin{tabular}{|c|c|c|c|c|}
\hline No & $\begin{array}{c}\text { Variabel } \\
\text { Sistem }\end{array}$ & Indikator & Uraian & $\begin{array}{l}\text { Skor } \\
(\%)\end{array}$ \\
\hline \multirow[t]{3}{*}{1.} & \multirow{3}{*}{$\begin{array}{l}\text { Computer } \\
\text { Self- } \\
\text { Efficacy }\end{array}$} & Magnitude & $\begin{array}{l}\text { Kemampuan menggunakan komputer atau } \\
\text { sistem tanpa bantuan orang lain }\end{array}$ & 55 \\
\hline & & Strenght & $\begin{array}{l}\text { Memiliki keyakinan terhadap } \\
\text { kemampuan } \\
\text { untuk melakukan tugas-tugas komputasi } \\
\text { dengan baik }\end{array}$ & 60 \\
\hline & & Generalizability & $\begin{array}{l}\text { Kemampuan menggunakan aplikasi e- } \\
\text { militer (Sispofers) dan komputer } \\
\text { dengan beragam } \\
\text { platform yang berbeda }\end{array}$ & 40 \\
\hline \multirow[t]{5}{*}{2.} & \multirow[t]{5}{*}{$\begin{array}{l}\text { Persepsi } \\
\text { Manfaat }\end{array}$} & Make job easier & $\begin{array}{l}\text { Aplikasi e-militer (Sispofers) mempermudah dan } \\
\text { mempercepat pertukaran informasi antar pesonil }\end{array}$ & 70 \\
\hline & & Usefulness & $\begin{array}{l}\text { Aplikasi e-militer (Sispofers) memiliki } \\
\text { manfaat sehingga termotivasi untuk } \\
\text { menggunakan kembali }\end{array}$ & 55 \\
\hline & & $\begin{array}{l}\text { Increase } \\
\text { productivity }\end{array}$ & $\begin{array}{l}\text { Produltivitas keja dan kualitas kimeja meningkat } \\
\text { setelah menggunakan Aplikasi e-militer } \\
\text { (Sispofers) (petugas menjadi sigap, cepat dan } \\
\text { tanggap) }\end{array}$ & 60 \\
\hline & & $\begin{array}{l}\text { Enchance } \\
\text { efectiveness }\end{array}$ & $\begin{array}{l}\text { e-militer mendorong pertukaran informasi } \\
\text { menjadi semakin cepat, tepat dan aman }\end{array}$ & 75 \\
\hline & & $\begin{array}{l}\text { Improve job } \\
\text { performance }\end{array}$ & $\begin{array}{l}\text { Kineja personil semakin meningkat (sigap, } \\
\text { tanggap dan handal) sejalan dengan } \\
\text { efektivitas implementasi e-militer }\end{array}$ & 60 \\
\hline \multirow[t]{4}{*}{3.} & \multirow[t]{4}{*}{$\begin{array}{l}\text { Kualitas } \\
\text { sistem }\end{array}$} & $\begin{array}{l}\text { Ketersediaan } \\
\text { peralatan }\end{array}$ & $\begin{array}{l}\text { Ketersediaan modem dan sarana prasarana } \\
\text { pendukung impelemntasi e-militer tersedia } \\
\text { dengan memadai dan mudah didapat }\end{array}$ & 50 \\
\hline & & $\begin{array}{l}\text { Keandalan } \\
\text { peralatan }\end{array}$ & $\begin{array}{l}\text { Ketersediaan jaringan dan perangkat lunak } \\
\text { pendukung implementasi e-militer memadai } \\
\text { dan memiliki daya tahan dan performa } \\
\text { yang baik }\end{array}$ & 50 \\
\hline & & $\begin{array}{l}\text { Kemudahan } \\
\text { untuk } \\
\text { digunakan } \\
\end{array}$ & $\begin{array}{l}\text { Aplikasi e-militer dirancang dengan } \\
\text { sederhana dan sangat mudah untuk } \\
\text { digunakan }\end{array}$ & 57 \\
\hline & & Waktu respon & $\begin{array}{l}\text { Waktu yang dibutuhkan untuk mengakses } \\
\text { dan menggunakan aplikasi e-militer sudah } \\
\text { sesuai harapan }\end{array}$ & 60 \\
\hline
\end{tabular}

\begin{tabular}{|c|c|c|c|c|}
\hline \multirow[t]{4}{*}{4.} & \multirow[t]{4}{*}{$\begin{array}{l}\text { Kualitas } \\
\text { Informasi }\end{array}$} & $\begin{array}{l}\text { Keakuratan } \\
\text { informasi }\end{array}$ & $\begin{array}{l}\text { Pertukaran informasi yang dihasilkan oleh } \\
\text { aplikasi e-militer tidak mengandung } \\
\text { kesalahan dan tidak menyesatkan }\end{array}$ & 70 \\
\hline & & $\begin{array}{l}\text { Kegunaan } \\
\text { informasi }\end{array}$ & $\begin{array}{l}\text { Informasi yang diha silkan oleh aplikasi e- } \\
\text { militer memiliki nilai yang dapat } \\
\text { dimanfaatkan (value added) }\end{array}$ & 60 \\
\hline & & $\begin{array}{l}\text { Relevansi } \\
\text { informasi }\end{array}$ & $\begin{array}{l}\text { Informasi yang dihasilkan oleh aplikasi e- } \\
\text { militer berkaitan dan sesuai kebutuhan }\end{array}$ & 65 \\
\hline & & $\begin{array}{l}\text { Kelengkapan } \\
\text { informasi }\end{array}$ & $\begin{array}{l}\text { Informasi yang dihasilkan oleh aplikasi e- } \\
\text { militer lengkap dan jelas serta handal }\end{array}$ & 65 \\
\hline \multirow[t]{4}{*}{5.} & \multirow[t]{4}{*}{ Penggunaan } & Actual use & $\begin{array}{l}\text { Menggunakan atau menjadi pengguna } \\
\text { langsung aplikasi e-militer }\end{array}$ & 70 \\
\hline & & Daily use & Menggunakan aplikasi e-militer setiap har & 70 \\
\hline & & $\begin{array}{l}\text { Frequency of } \\
\text { use }\end{array}$ & $\begin{array}{l}\text { Intensitas penggunaan aplikasi e-militer } \\
\text { sangat sering attau rutin }\end{array}$ & 60 \\
\hline & & Nature of use & $\begin{array}{l}\text { Alasan menggunakan e-militer adalah } \\
\text { kemauan/motivasi sendir atau sukarela }\end{array}$ & 60 \\
\hline \multirow[t]{5}{*}{6.} & \multirow[t]{5}{*}{$\begin{array}{l}\text { Kepuasan } \\
\text { pengguna }\end{array}$} & Content & $\begin{array}{l}\text { Komponen dan fitur aplikasi e-militer } \\
\text { memuaskan }\end{array}$ & 60 \\
\hline & & Accuracy & $\begin{array}{l}\text { Kesesuain input dan output yang diha silkan } \\
\text { oleh aplikasi e-militer memuaskan }\end{array}$ & 65 \\
\hline & & Format & $\begin{array}{l}\text { Tampilan atau layout dan fitur aplikasi e- } \\
\text { militer memuaskan }\end{array}$ & 65 \\
\hline & & Ease & $\begin{array}{l}\text { Tata cara dan langkah-langkah penggunaan } \\
\text { aplikasi e-militer mudah dimemgerti dan } \\
\text { mudah diterapkan (user friendly) }\end{array}$ & 65 \\
\hline & & Timeliness & $\begin{array}{l}\text { Pemanfaatan aplikasi e-militer dapat } \\
\text { mendukung efektivitas dan efisiensi waktu } \\
\text { pengguna }\end{array}$ & 65 \\
\hline
\end{tabular}

Sumber: Hasil Penelitian, diolah (2020)

The researcher calculates the net benefit from the implementation of e-military applications on Kodam IX / Udayana which will be explained in Figure 3:

\begin{tabular}{|c|c|c|c|c|}
\hline No & $\begin{array}{l}\text { Variabel } \\
\text { Sistem }\end{array}$ & Indikator & $\begin{array}{l}\text { Skor } \\
(\%)\end{array}$ & Keterangann \\
\hline \multirow[t]{3}{*}{1.} & \multirow{3}{*}{$\begin{array}{l}\text { Computer } \\
\text { Self- } \\
\text { Efficacy }\end{array}$} & Magnitude & 55 & \multirow{4}{*}{$\begin{array}{l}\text { Nilai rata-rata Net Benefit kemampuan } \\
\text { personil dalam menggunakan aplikasi e- } \\
\text { militer (CSE) menunjukkan nilai sebesar } \\
51,67 \% \text { yang artinya kemampuan personil } \\
\text { menggunakan aplikais e militer adalah } \\
\text { kurang baik atau rendah }\end{array}$} \\
\hline & & Strenght & 60 & \\
\hline & & \begin{tabular}{|l|} 
Generalizability \\
\end{tabular} & 40 & \\
\hline \multicolumn{4}{|c|}{$\begin{array}{c}\text { Net Benefits } \\
\mathbf{5 1 , 6 7 \%}\end{array}$} & \\
\hline \multirow[t]{5}{*}{2.} & \multirow{5}{*}{$\begin{array}{l}\text { Persepsi } \\
\text { Manfaat }\end{array}$} & Make job easier & 70 & \multirow{6}{*}{$\begin{array}{l}\text { Nilai rata-rata Net Benefit manfaat yang } \\
\text { diharapkan (persepsi manfaat) yang } \\
\text { diharpkan pengguna dalam menggunakan } \\
\text { aplikasi e-militer menunjukkan nilai sebesar } \\
64,00 \% \text { yang artinya pengguna memiliki } \\
\text { harapan yang cukup baik atas manfaat yang } \\
\text { diharapkan dani implementasi aplikais e- } \\
\text { militer. }\end{array}$} \\
\hline & & Usefulness & 55 & \\
\hline & & $\begin{array}{l}\text { Increase } \\
\text { productivity }\end{array}$ & 60 & \\
\hline & & $\begin{array}{l}\text { Enchance } \\
\text { efectiveness }\end{array}$ & 75 & \\
\hline & & $\begin{array}{l}\text { Improve job } \\
\text { performance }\end{array}$ & 60 & \\
\hline \multicolumn{4}{|c|}{$\begin{array}{l}\text { Net Benefits } \\
64,00 \%\end{array}$} & \\
\hline \multirow[t]{4}{*}{3.} & \multirow[t]{4}{*}{$\begin{array}{l}\text { Kualitas } \\
\text { sistem }\end{array}$} & $\begin{array}{l}\text { Ketersediaan } \\
\text { peralatan }\end{array}$ & 50 & \multirow{4}{*}{$\begin{array}{l}\text { Dani sisi kualitas sistem responden } \\
\text { menyatakan kualitas sistem atau aplikasi e- } \\
\text { militer cukup baik dengan nilai net benefits } \\
\text { rata-rata sebesar } 54,25 \%\end{array}$} \\
\hline & & $\begin{array}{l}\text { Keandalan } \\
\text { peralatan }\end{array}$ & 50 & \\
\hline & & $\begin{array}{l}\text { Kemudahan } \\
\text { untuk } \\
\text { digunakan }\end{array}$ & 57 & \\
\hline & & Waktu respon & 60 & \\
\hline \multicolumn{4}{|c|}{$\begin{array}{l}\text { Net Benefits } \\
\mathbf{5 4 , 2 5} \%\end{array}$} & \\
\hline \multirow[t]{4}{*}{4.} & \multirow[t]{4}{*}{$\begin{array}{l}\text { Kualitas } \\
\text { Informasi }\end{array}$} & $\begin{array}{l}\text { Keakuratan } \\
\text { informasi }\end{array}$ & 70 & \multirow{4}{*}{$\begin{array}{l}\text { Dan sisi kualitas informasi menunjukkan } \\
\text { bahwa kualitas informasi yang dihasilkan } \\
\text { dan aplikasi e-militer adalah cukup baik, } \\
\text { dengan nilai rata-rata sebesar } 65,00 \%\end{array}$} \\
\hline & & $\begin{array}{l}\text { Kegunaan } \\
\text { informasi }\end{array}$ & 60 & \\
\hline & & $\begin{array}{l}\text { Relevansi } \\
\text { informasi }\end{array}$ & 65 & \\
\hline & & $\begin{array}{l}\text { Kelengkapan } \\
\text { informasi }\end{array}$ & 65 & \\
\hline
\end{tabular}

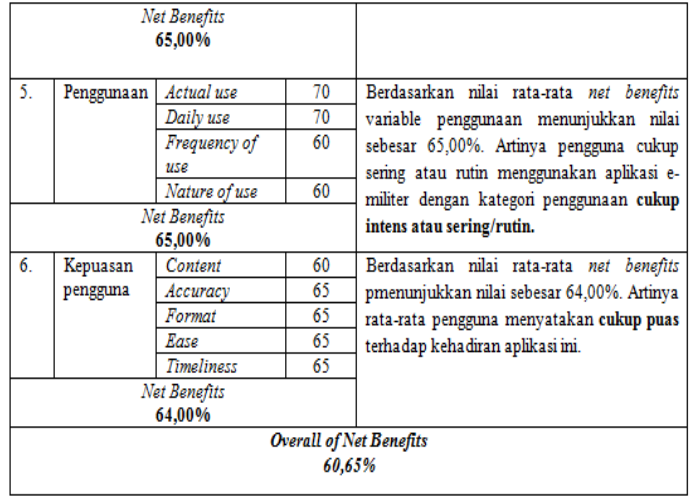

Sumber: Hasil Penelitian, diolah (2020)

Utomo, I. G. W., \& Darma, G. S. (2020). Measuring optimization of digital military programs: an innovation of information and communication systems in industrial digitalization 4.0. International Research Journal of Engineering, IT \& Scientific Research, 6(2), 39-46. https://doi.org/10.21744/irjeis.v6n2.862 
Based on Figure 3. as a whole it can be seen that the value of the benefits felt by users (personnel) of Kodam IX / Udayana towards the implementation of e-military (Sisfopers) is 60.65\%. The figure shows that the implementation of the Military Digital Program is a form of IT utilization and communication development in the Era of Industrial Digitalization 4.0 at Kodam IX / Udayana is "Good Enough". In terms of the quality of the system, the quality of information, the intensity of use or use of applications to the level of satisfaction of users of e-military applications shows a response that is "quite good". However, in terms of the ability of personnel to use the system independently, they show "poor/low" results, this is caused by various internal and external constraints (Almazán et al., 2017; Anatan \& Ellitan, 2007).

Internal constraints experienced and solutions offered include efforts to improve the quality and competence of human resources through education, training, and development of competency in the use of e-military applications. Efforts to propose additional capacity of infrastructure to support program optimization. Constraints related to the low motivation of personnel towards the use of IT-based applications are overcome by providing preventive education designed to increase personnel motivation. Obstacles related to coordination among personnel are still low offered a solution by increasing the capacity and capability of personnel through education and training and investment in values related to technology. External constraints experienced and solutions offered are low network quality, wide-area coverage, unequal network availability, unequal staff competence, rapid TNI mutations. Constraints obtained in this study have been proposed and are in the process of follow-up in order to increase the quality of e-military implementation within the Army.

\section{Conclusion}

Based on the review of the discussion of research results it can be concluded that the implementation of Military Digital Applications at Kodam IX / Udayana is quite good. Internal and external obstacles are still encountered in the implementation of the program. The implication of this research from a theoretical point of view is being able to prove the role of Delone and McLean's information system success model theory in explaining how the implementation and Optimization of Military Digital Applications is a form of TNI's commitment to adopt IT development in improving the quality of performance and personnel communication in the Industrial Digitization Era 4.0 at Kodam IX / Udayana Denpasar, Bali. This research contributes to the development of the quality of the implementation of the TNI-AD e-military program, especially e-military applications (Sisfopers) as a form of information technology communication and innovation based on information technology, especially at Kodam IX / Udayana, Denpasar, Bali. If possible further research with the same theme can examine the changes that have occurred and add data variants in this study, especially on aspects that have not been explored in this study.

\section{Conflict of interest statement}

The authors declared that they have no competing interests.

\section{Statement of authorship}

The authors have a responsibility for the conception and design of the study. The authors have approved the final article.

\section{Acknowledgments}

We are grateful to two anonymous reviewers for their valuable comments on the earlier version of this paper. 


\section{References}

Almazán, D. A., Tovar, Y. S., \& Quintero, J. M. M. (2017). Influence of information systems on organizational results. Contaduría y Administración, 62(2), 321-338. https://doi.org/10.1016/j.cya.2017.03.001.

Almazán, D. A., Tovar, Y. S., \& Quintero, J. M. M. (2017). Influence of information systems on organizational results. Contaduría y Administración, 62(2), 321-338. https://doi.org/10.1016/j.cya.2017.03.001

Anatan, L., \& Ellitan, L. (2007). Manajemen Sumber Daya Manusia dalam Bisnis Modern. Bandung: Alfabeta.

Azhari, A., Schindler, C., \& Li, B. (2013). Effect of waterjet peening on aluminum alloy 5005. The International Journal of Advanced Manufacturing Technology, 67(1-4), 785-795.

Castillo, G. A. L., Albuerne, Y. E. L., Fernández, M. C., \& Alava, L. A. C. (2016). General information about the design of smart grids in universities. International Research Journal of Engineering, IT \& Scientific Research, 2(9), 59-66.

DeLone, W. H., \& McLean, E. R. (1992). Information systems success: The quest for the dependent variable. Information systems research, 3(1), 60-95. https://doi.org/10.1287/isre.3.1.60

Delone, W. H., \& McLean, E. R. (2003). The DeLone and McLean model of information systems success: a ten-year update. Journal of management information systems, 19(4), https://doi.org/10.1080/07421222.2003.11045748

Dewi, I. G. A. A. O., Dewi, I. G. A. A. P., Kustina, K. T., \& Prena, G. D. (2018). Culture of tri hita karana on ease of use perception and use of accounting information system. International Journal of Social Sciences and Humanities, 2(2), 77-86. https://doi.org/10.29332/ijssh.v2n2.131

Huang, C. Y., \& Nof, S. Y. (2002). Evaluation of agent-based manufacturing systems based on a parallel simulator. Computers \& industrial engineering, 43(3), 529-552. https://doi.org/10.1016/S0360-8352(02)00124-9

Juniar, M. (2013). Studi Tentang Implementasi Program Sanitasi Total dan Pemasaran Sanitasi (StoPs) dalam Perspektif Deliberatif di Desa Ngampungan Kecamatan Bareng Kabupaten Jombang. Jurnal Kebijakan dan Manajemen Publik, 1(1), 120-129.

McLeod, R., \& Schell, G. (2004). Sistem informasi manajemen. Indeks.

Peraturan Kasad Nomor Perkasad/20/VIII/ Tahun 2012 Tentang Penggunaan sistem informasi di lingkungan Tentara Nasional Indonesia Angkatan Darat.

Teguh, M. (2005). Metodologi Penelitian Ekonomi Teori dan Aplikasi.

Xavier, I. M. D. D. G. (2015). Email issue for working at information technology field. International Research Journal of Management, IT and Social Sciences, 2(5), 1-5.

Yoga, I. M. S., Korry, N. P. D. P., \& Yulianti, N. M. D. R. (2019). Information technology adoption on digital marketing communication channel. International Journal of Social Sciences and Humanities, 3(2), 95-104. https://doi.org/10.29332/ijssh.v3n2.297

Utomo, I. G. W., \& Darma, G. S. (2020). Measuring optimization of digital military programs: an innovation of information and communication systems in industrial digitalization 4.0. International Research Journal of Engineering, IT \& Scientific Research, 6(2), 39-46. https://doi.org/10.21744/irjeis.v6n2.862 


\section{Biography of Authors}

\begin{tabular}{|l|l||}
\hline I Gd. Wahyu Utomo was Born in Sembung, 8 Agust 1988. Now he is 32 years old, and \\
now he still became a student in Undiknas Graduate Scholl especially in magister \\
public administrations programme. He also became a The Indonesian National Armed \\
Forces especially in IT and administration staff. \\
Email: kambingcowok@gmail.com
\end{tabular}

